\title{
Fire intensity impacts on post-fire temperate coniferous forest net primary productivity
}

\author{
Aaron M. Sparks ${ }^{1}$, Crystal A. Kolden ${ }^{1}$, Alistair M. S. Smith ${ }^{1}$, Luigi Boschetti ${ }^{1}$, Daniel M. Johnson ${ }^{1}$, and \\ Mark A. Cochrane ${ }^{2}$ \\ ${ }^{1}$ College of Natural Resources, University of Idaho, Moscow, ID 83843, USA \\ ${ }^{2}$ Appalachian Laboratory, University of Maryland, Frostburg, MD 21532, USA
}

Correspondence: Aaron M. Sparks (asparks@uidaho.edu)

Received: 26 August 2017 - Discussion started: 30 August 2017

Revised: 12 January 2018 - Accepted: 27 January 2018 - Published: 27 February 2018

\begin{abstract}
Fire is a dynamic ecological process in forests and impacts the carbon (C) cycle through direct combustion emissions, tree mortality, and by impairing the ability of surviving trees to sequester carbon. While studies on young trees have demonstrated that fire intensity is a determinant of post-fire net primary productivity, wildland fires on landscape to regional scales have largely been assumed to either cause tree mortality, or conversely, cause no physiological impact, ignoring the impacted but surviving trees. Our objective was to understand how fire intensity affects post-fire net primary productivity in conifer-dominated forested ecosystems on the spatial scale of large wildland fires. We examined the relationships between fire radiative power (FRP), its temporal integral (fire radiative energy - FRE), and net primary productivity (NPP) using 16 years of data from the MOderate Resolution Imaging Spectrometer (MODIS) for 15 large fires in western United States coniferous forests. The greatest NPP post-fire loss occurred 1 year post-fire and ranged from -67 to $-312 \mathrm{~g} \mathrm{C} \mathrm{m}^{-2} \mathrm{yr}^{-1}(-13$ to $-54 \%)$ across all fires. Forests dominated by fire-resistant species (species that typically survive low-intensity fires) experienced the lowest relative NPP reductions compared to forests with less resistant species. Post-fire NPP in forests that were dominated by fire-susceptible species were not as sensitive to FRP or FRE, indicating that NPP in these forests may be reduced to similar levels regardless of fire intensity. Conversely, post-fire NPP in forests dominated by fire-resistant and mixed species decreased with increasing FRP or FRE. In some cases, this dose-response relationship persisted for more than a decade post-fire, highlighting a legacy effect of fire intensity on postfire $\mathrm{C}$ dynamics in these forests.
\end{abstract}

\section{Introduction}

Forested ecosystems cover $\sim 30 \%$ of Earth's land surface and serve as one of the largest terrestrial carbon (C) sinks (Bonan, 2008; IPCC, 2013). Dynamic ecological processes such as wildfires impact this sink through direct $\mathrm{C}$ emissions from combustion, loss of $\mathrm{C}$ uptake through tree mortality, decomposition processes, and sequestration of black $\mathrm{C}$ within forest soils (Bowman et al., 2009; Brewer et al., 2013; Tinkham et al., 2016). Recent research has demonstrated that greater fire intensity impairs the ability of surviving saplings to photosynthesize (Smith et al., 2016, 2017). However, on landscape spatial scales, while many studies have examined and projected post-fire trends in forest productivity (Goetz et al., 2007; Hicke et al., 2003; Kashian et al., 2006; Romme et al., 2011), none have evaluated relationships between the fire intensity and those trends. Characterization of such relationships is essential given that both lower fuel moisture (Gergel et al., 2017) and increased fire activity (frequency, intensity, and area burned) are predicted in North American forested ecosystems undergoing anthropogenic climate change (Balshi et al., 2009; de Groot et al., 2013; IPCC, 2013; Barbero et al., 2015; Abatzoglou and Williams, 2016; Bowman et al., 2017).

Recent studies have observed that increasing fire radiative energy (FRE: $J$ ) and peak fire radiative power (FRP: $W$ ) incident on trees results in reduced tree growth and increased mortality (Smith et al., 2017; Sparks et al., 2016, 2017). FRP is the instantaneous radiative flux, which is strongly related to common field-based fire intensity metrics (Kaufman et al., 1996; Kremens et al., 2012; Sparks et al., 2017), and its temporal integral is FRE. These are two of the most com- 
monly used metrics to quantify fire intensity from satellite remote sensing products (Andela et al., 2015; Freeborn et al., 2016; Heward et al., 2013; Roberts et al., 2011; Smith and Wooster, 2005). Under controlled experiments on saplings, a toxicological "dose-response" relationship was observed, whereby increasing FRE resulted in decreasing net photosynthesis in surviving Pinus contorta and Larix occidentalis saplings (Smith et al., 2016, 2017) and increased mortality 1 year post-fire (Sparks et al., 2016). Furthermore, Sparks et al. (2017) observed decreasing radial growth in mature Pinus ponderosa 1.5 years post-fire with increasing peak FRP. These findings suggest that there is a strong link between measures of fire intensity and subsequent vegetation productivity and mortality.

Prior studies have been limited to the spatial scale of the individual plant and only up to $\sim 1.5$ years following fire treatments. They have also not evaluated how relative fire resistance, or the ability of a tree species to withstand and survive heat-induced damage from fire (Midgley et al., 2011; Starker, 1934; VanderWeide and Hartnett, 2011), may affect the observed dose-response relationship. Numerous studies have linked morphological traits to post-fire survival; thicker bark, deep rooting depth, and a high, open tree crown have all been identified as characteristics that increase the relative fire resistance of a tree (Fischer and Bradley, 1987; Harrington, 2013; He et al., 2012; Keeley, 2012; Midgley et al., 2011; Ryan and Reinhardt, 1988; Starker, 1934; VanderWeide and Hartnett, 2011). However, many studies assume a binary response regarding fire impacts on vegetation: either mortality (immediate or delayed) or no physiological effect (Smith et al., 2017). Consequently, there is a need to investigate if dose-response relationships can be quantified on larger spatial and temporal scales and across forest stands dominated with species of varying levels of fire resistance.

Active and post-fire observations from MODIS provide an avenue to expand previous dose-response studies to a landscape spatial scale and across decadal temporal scales. Terra and Aqua satellites can observe active fires up to four times daily at $1 \mathrm{~km}$ resolution at nadir (Justice et al., 2002), enabling the coarse integration of FRP over the duration of a fire, described as fire radiative energy (Boschetti and Roy, 2009; Kumar et al., 2011). However, the relatively low temporal resolution results in significant underestimations of FRE when compared with higher temporal resolution sensors (Vermote et al., 2009). MODIS observations have also enabled global estimations of gross primary production (GPP: the total amount of $\mathrm{C}$ fixed by vegetation) and net primary production (NPP: GPP minus C losses to respiration) when used in tandem with local meteorological data (Running et al., 2004; Zhao and Running, 2010). These estimates have been critical to understanding $\mathrm{C}$ fluxes and forest disturbances over large spatial extents (Bright et al., 2013; Zhao and Running, 2010). Given the lack of landscape-scale studies that quantify fire intensity and species composition impacts on post-fire $\mathrm{C}$ dynamics, the objective here was to un- derstand how fire intensity affects post-fire productivity in conifer-dominated forested ecosystems. Our results provide further insight into post-fire $\mathrm{C}$ dynamics and a framework for spatiotemporal assessments of fire effects.

In this study, we sought to answer the following questions:

1. What are the relationships between fire intensity (i.e., FRP and FRE) and post-fire forest NPP on spatial scales of large wildland fires?

2. How do these relationships vary over time?

3. How do these relationships vary with species composition?

\section{Methodology}

\subsection{Wildland fire selection}

A total of 15 wildland fires in the northwestern US were selected for this study (Fig. 1). Fires were chosen to represent coniferous forest stands ranging from those dominated by fire-resistant species to those dominated by fire-susceptible species. Forests dominated by fire-resistant species were typically composed of Pseudotsuga menziesii, Pinus ponderosa, Larix occidentalis, and lesser quantities of Abies grandis. Forests dominated by fire-susceptible species were typically composed of Picea engelmannii, Abies lasiocarpa, Pinus contorta, and lesser quantities of Pinus albicaulis. To assess the pre-fire dominant forest cover for each fire, we used the LANDFIRE Existing Vegetation Type (EVT) $30 \mathrm{~m}$ product (LANDFIRE, 2013). Fire selection was based on the following criteria:

i. Located in northwestern United States temperate forests to minimize latitudinal climatological gradients;

ii. Located completely within a designated wilderness or other protected area to minimize confounding factors such as land management disturbance;

iii. Must have occurred in a closed canopy (mean canopy cover $>60 \%$ ), conifer-dominated forest to minimize mixed pixels;

iv. Located in forests where the majority of fire-affected area has not been observed to have burned in the last $\sim 30$ years; and

v. Each fire must have at least 3 years of pre- and post-fire MODIS NPP estimates.

Pre-fire canopy cover was determined by aggregating the $30 \mathrm{~m}$ National Land Cover Database (NLCD) Percent Tree Canopy product (Homer et al., 2007) to the $1 \mathrm{~km}$ spatial resolution of the MODIS products. We used the Landsat-derived Monitoring Trends in Burn Severity (MTBS) fire polygons 
Table 1. Summary of the 15 fires analyzed in this study.

\begin{tabular}{|c|c|c|c|c|c|}
\hline Fire name & $\begin{array}{l}\text { Size } \\
\text { (ha) }\end{array}$ & Dominant conifer species* & $\begin{array}{l}\text { Ignition } \\
\text { date }\end{array}$ & $\begin{array}{r}\text { Proportion of } \\
\text { MTBS polygon } \\
\text { burned (1984- } \\
\text { ignition date) }(\%)\end{array}$ & $\begin{array}{r}\text { Proportion of } \\
\text { MTBS polygon } \\
\text { with MODIS FRP } \\
\text { observations }(\%)\end{array}$ \\
\hline Ahorn & 18778 & PSME, PIPO, LAOC, PIEN, ABLA, PIAL & 28 June 2007 & 0 & 86.2 \\
\hline Arnica & 4556 & PICO & 23 September 2009 & 0 & 76.9 \\
\hline Bridge & 15116 & $P I E N, A B L A$ & 18 July 2007 & 8.9 & 91.0 \\
\hline Columbine & 7115 & PIEN, ABLA, PIAL & 9 August 2007 & 1.6 & 91.2 \\
\hline East & 7145 & PIEN, ABLA, PIAL, PICO & 8 August 2003 & 0.6 & 93.6 \\
\hline Fawn Peak & 31870 & PSME, PIPO, LAOC, PIEN, ABLA, PIAL & 30 June 2003 & 0.3 & 91.8 \\
\hline Fool Creek & 22186 & $P I E N, A B L A, P I A L$ & 28 June 2007 & 2.0 & 89.9 \\
\hline Little Salmon & 13598 & PSME, PIPO, LAOC, PIEN, ABLA & 18 July 2003 & 0.1 & 78.2 \\
\hline Meriwether & 7762 & PSME, PIPO, LAOC & 21 July 2007 & 0.2 & 98.1 \\
\hline North Fork & 6774 & $P S M E, P I P O$ & 1 August 2009 & 1.1 & 92.1 \\
\hline Saddle & 12706 & PSME, PIPO, LAOC, PIEN, ABLA & 18 August 2011 & 0.2 & 80.1 \\
\hline Sawmill & 6015 & $P S M E, P I P O, L A O C$ & 13 July 2007 & 3.0 & 95.5 \\
\hline Shower Bath & 19911 & PSME, PIPO & 17 July 2007 & 1.1 & 78.0 \\
\hline South Fork & 11494 & PSME, PIPO & 7 August 2006 & 1.2 & 82.3 \\
\hline Tatoosh & 20185 & PSME, PIPO, LAOC, PIEN, ABLA, PIAL & 22 August 2006 & 2.3 & 92.4 \\
\hline
\end{tabular}

* Conifer species codes: ABLA - Abies lasiocarpa, LAOC - Larix occidentalis, PIAL - Pinus albicaulis, PICO - Pinus contorta, PIEN - Picea engelmannii, PIPO - Pinus ponderosa, PSME - Pseudotsuga menziesii.

to estimate whether a forest had burned since 1984 (Eidenshink et al., 2007). MTBS does not typically map fires smaller than $\sim 404$ ha, so smaller burned areas within each selected fire perimeter were mapped using the Normalized Burn Ratio Thermal Index (Holden et al., 2005) computed by Google Climate Engine (http://climateengine.org) annually from 1984 to the present. Google Climate Engine uses data from Landsat 4, 5, 7, and 8 , depending on availability and cloud cover, to produce $30 \mathrm{~m}$ spatial resolution datasets. Summary information for each fire is given in Table 1.

\subsection{MODIS datasets}

For each fire, we assessed post-fire NPP trajectories as a function of colocated FRP using MODIS NPP and FRP products. We used the MOD17A3 version $0551 \mathrm{~km}$ NPP product $\left(\mathrm{kg} \mathrm{C} \mathrm{m}^{-2} \mathrm{yr}^{-1}\right)$ to characterize changes in productivity within and between our study fires. The NPP product is detailed in Running et al. (2004) and Hasenauer et al. (2012). MODIS land cover, FPAR (fraction of photosynthetically active radiation), and LAI (leaf area index) products are used in tandem with meteorological data (incoming photosynthetically active radiation, stress scalars for high vapor pressure deficit and temperature) and physiological parameters for different vegetation types to calculate daily GPP. NPP is calculated as the sum of GPP over a year minus maintenance and growth respiration. We acquired the NPP product from the Numerical Terradynamic Simulation Group (NTSG) at the University of Montana. NPP data for years 2000-2015 were downloaded from the NTSG FTP site and analyzed in the native sinusoidal equal area projection.

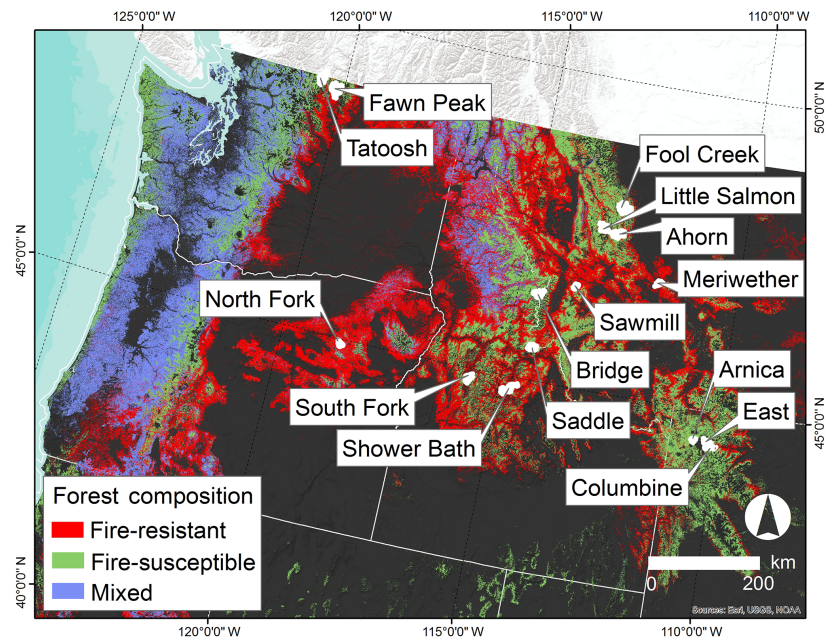

Figure 1. Location of study fires overlaid on the pre-fire distribution of US forest types classified using relative fire resistance information in the literature and the LANDFIRE Existing Vegetation Type (EVT) $30 \mathrm{~m}$ product.

To calculate FRP metrics colocated with each NPP pixel we used the Collection 6 MODIS $1 \mathrm{~km}$ Level 2 active fire product that identifies and quantifies active fire detections from NASA Terra (MOD14) and Aqua (MYD14) satellites (Giglio et al., 2016). MODIS FRP is derived from the linear relationship between midinfrared $(4 \mu \mathrm{m})$ spectral radiance and FRP (Wooster et al., 2003) and is affected by several factors, including fire background characterization and atmospheric water vapor (Wooster et al., 2005). The $1 \mathrm{~km}$ 
spatial resolution MOD14 and MYD14 products provide an active fire mask showing which pixels contain active fire as well as the date, time, FRP, and other ancillary data (Giglio, 2015). Following Boschetti and Roy (2009), MOD14 and MYD14 data were projected to the $1 \mathrm{~km}$ MODIS sinusoidal projection using nearest-neighbor resampling. Importantly, this methodology accounts for increasing MODIS pixel size at large scan angles (Wolfe et al., 1998) so that the location of fire detections and total FRP is preserved post-reprojection. The resulting range of FRP for all fires was comparable to FRP observed in other closed-canopy temperate forests (Giglio et al., 2006; Heward et al., 2013). We used MTBS fire perimeters and metadata to screen any fire detections that were not colocated with recorded fire events spatially and temporally. Fire detections outside the MTBS perimeter were included in the subsequent analysis if they were closer than $1000 \mathrm{~m}$ from the MTBS fire boundary (as fires can occur anywhere in the $1 \mathrm{~km}$ FRP product). On average, FRP observations were available for $>88 \%$ of the area within the MTBS fire polygons (Table 1).

\subsection{Data analysis}

We calculated FRP distributional statistics (peak, 90th percentile, mean) and FRE for each fire-affected pixel. FRE was calculated following Boschetti and Roy (2009), where FRP values are integrated over time assuming that FRP varies linearly between observations. FRP and FRE metrics were chosen as they have been demonstrated to have a dose-response relationship with conifer growth and mortality (Smith et al., 2016, 2017; Sparks et al., 2017). Fire-affected pixels were grouped by FRP and FRE percentile classes $(0-25,25-50$, $50-75,75-100)$ for each forest type (fire-susceptible, fireresistant, mixed). Unburned pixels were manually selected outside the MTBS fire perimeters to serve as "control" pixels. Control pixels were selected if they (1) were within a $5 \mathrm{~km}$ buffer of the MTBS perimeter, (2) were in the same forest type as the fire-affected pixels, and (3) had pre-fire mean NPP within $\pm 50 \mathrm{~g} \mathrm{C} \mathrm{m}^{-2} \mathrm{yr}^{-1}$ of pre-fire mean NPP of fireaffected pixels. Pre- and post-fire NPP were used to calculate the percent deviation from mean pre-fire NPP, or relative NPP, for each pixel $(i, j)$ and year $(t)$, which was calculated following Eq. (1):

Relative $\mathrm{NPP}_{t}(\%)=\frac{\left(\mathrm{NPP}_{i, j, t}-\overline{\mathrm{NPP}}_{\text {prefire }(i, j)}\right)}{\overline{\mathrm{NPP}}_{\text {prefire }(i, j)}}$.

To account for interannual variability in NPP not caused by the fires we subtracted the unburned (control) pixel values from the burned pixel values (Bright et al., 2013; Goetz et al., 2006). After confirming normality and homogeneity of variances, differences between FRP percentile classes were assessed using ANOVA with a post hoc Tukey's honest significant difference test $(\alpha=0.05)$. Recovery time for the fire affected pixels was also assessed and was defined as the time
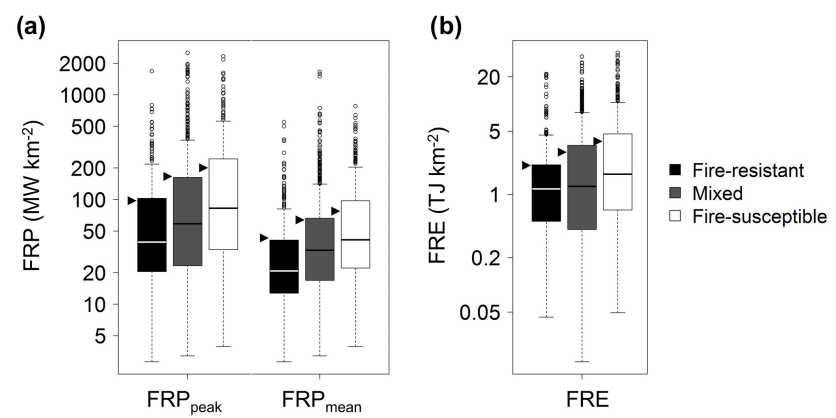

Figure 2. Fire radiative power (a) and fire radiative energy (b) distributional statistics grouped by dominant forest composition (fireresistant to fire-susceptible). Black arrows indicate mean values.

necessary for post-fire mean NPP to equal or surpass mean pre-fire NPP at the same location.

\section{Results}

\subsection{Fire intensity differences between forest types}

Fires in forests dominated by fire-susceptible species were more intense, in terms of FRP metrics and FRE, than those dominated by a mix of species or fire-resistant species (Fig. 2). This finding is consistent with other observations in these, and similar, forest types where lower-biomass, opencanopy forests dominated by fire-resistant species tend to support lower intensity fires, and higher biomass, closedcanopy forests dominated by fire-susceptible species tend to support higher intensity fires (Shinneman and Baker, 1997; Morgan et al., 2001; Schoennagel et al., 2004; Rogers et al., 2015).

\subsection{Higher fire intensity results in lower post-fire NPP}

For fires that occurred in forests dominated by a mix of species or fire-resistant species, higher FRP or FRE magnitude resulted in lower post-fire NPP. This dose-response relationship was most apparent 1 year post-fire, where mean relative NPP decreased with increasing FRP and FRE (Fig. 3). For forests dominated by fire-resistant species and mixed forests, the dose-response pattern was very similar regardless of whether relative NPP was grouped by FRE or FRP percentile classes (Figs. 4, S1 in the Supplement). The observed dose-response relationship for these forest types persisted for $>8$ years post-fire, especially in forests dominated by mixed species (Fig. 4a, b, column 2). In forests dominated by fire-susceptible species (Fig. 4a, b, column 3) there were few differences between percentile classes with only the highest FRE percentile class displaying lower NPP compared with the other percentile classes (Fig. 4b). 

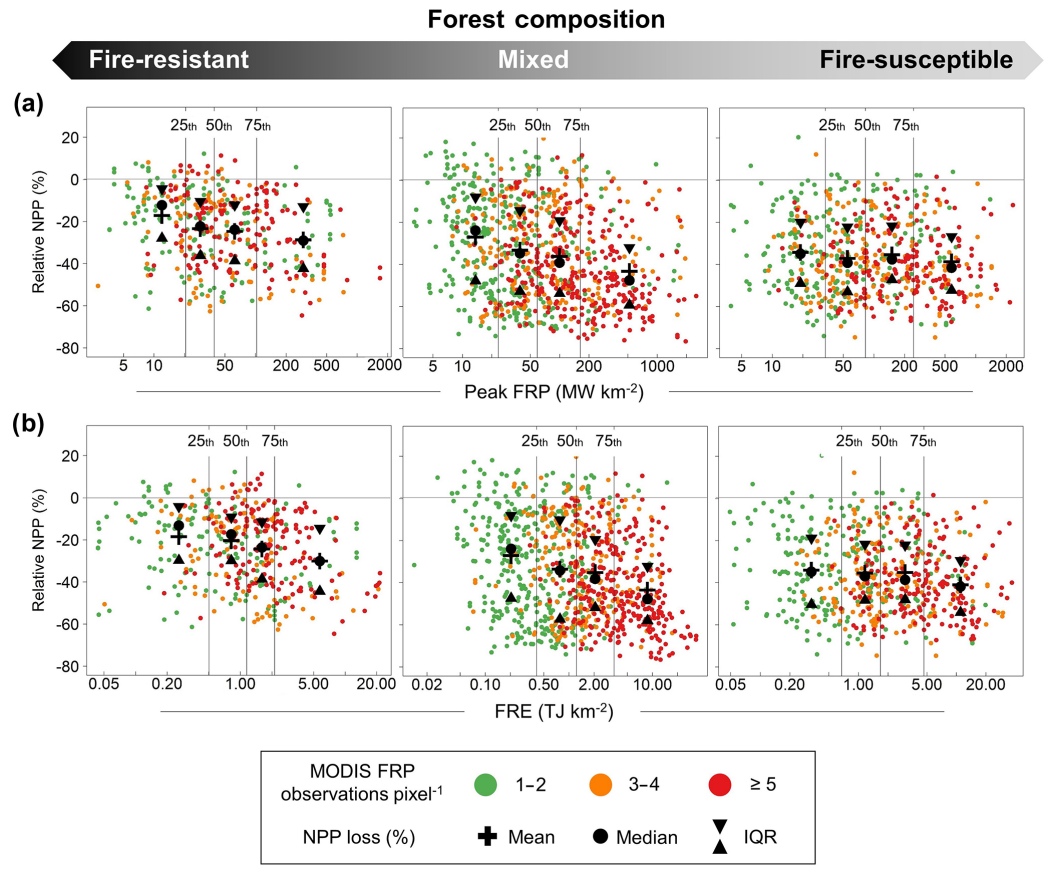

Figure 3. Fire intensity impacts on 1-year post-fire NPP observed in forests dominated by species varying from fire-resistant to firesusceptible (first column-third column). Distributional statistics are shown for NPP grouped by (a) peak FRP percentile class and (b) FRE percentile class.

Maximum relative NPP loss occurred at 1 year post-fire for all fires and differed by species composition. Generally, mixed stands consisting of fire-susceptible and fire-resistant species had the largest relative post-fire NPP losses with an average loss of $40.7 \%\left(-216.7 \mathrm{~g} \mathrm{C} \mathrm{m}^{-2} \mathrm{yr}^{-1}\right)$, followed by stands that were dominated by fire-susceptible species with an average loss of $33.9 \%\left(-154.8 \mathrm{~g} \mathrm{C} \mathrm{m}^{-2} \mathrm{yr}^{-1}\right)$. Stands dominated by fire-resistant species had the smallest average loss of $23.3 \%\left(-126.8 \mathrm{~g} \mathrm{C} \mathrm{m}^{-2} \mathrm{yr}^{-1}\right)$.

\subsection{Recovery and trajectories of post-fire NPP}

Post-fire observations ranged from 4 to 12 years post-fire (average 8.4 years) for the 15 fires, however, only the lowest FRP class of one fire (2006 South Fork Fire) had recovered to pre-fire NPP levels at the end of the observational period ( $\sim 9$ years post-fire). While some fires displayed linear recovery trajectories, most exhibited nonlinear trajectories where NPP increased until $\sim 2011$ and then began decreasing again or leveling off (Figs. S2-S4).

\section{Discussion}

\subsection{Higher fire intensity results in lower post-fire NPP}

To date, research has largely analyzed post-fire forest productivity with fire as a binary predictor variable (presenceabsence). In the current study, we applied a dose-response methodology that has been demonstrated on the tree scale (Smith et al., 2016, 2017; Sparks et al., 2016, 2017) to large fires using landscape remote sensing datasets. A doseresponse relationship between FRP or FRE and NPP was shown in forests dominated by fire-resistant species and mixed species (Figs. 3 and 4, columns 1-2). Forests that were dominated by fire-susceptible species were not as sensitive to FRP or FRE, indicating that NPP in these forests may be reduced to similar levels regardless of fire intensity (Figs. 3 and 4, column 3). Additionally, forests dominated by fire-resistant species had lower post-fire relative NPP losses compared to those dominated by fire-susceptible species or a mix (Fig. 4). These data are congruent with evidence on the tree scale where trees that do not develop fire-resistant traits, such as thick bark, have a higher probability of fire-induced damage and mortality (Midgley et al., 2011; Ryan and Reinhardt, 1988; VanderWeide and Hartnett, 2011). NPP loss at 2 years post-fire $\left(\sim 19-152 \mathrm{~g} \mathrm{C} \mathrm{m}^{-2} \mathrm{yr}^{-1}\right)$ in forests dominated by fire-resistant species is comparable to 2-year post-fire aboveground NPP differences between unburned and burned temperate Pinus ponderosa forest stands $\left(\sim 83-148 \mathrm{~g} \mathrm{C} \mathrm{m}^{-2} \mathrm{yr}^{-1}\right)$, estimated using field measurements (Irvine et al., 2007).

There was considerable variability in the dose-response relationships within each fire resistance grouping, which could potentially be attributed to differences in stand structure and age as well as differing proportions of burned and unburned area within each NPP pixel (mixed pixels). Previ- 


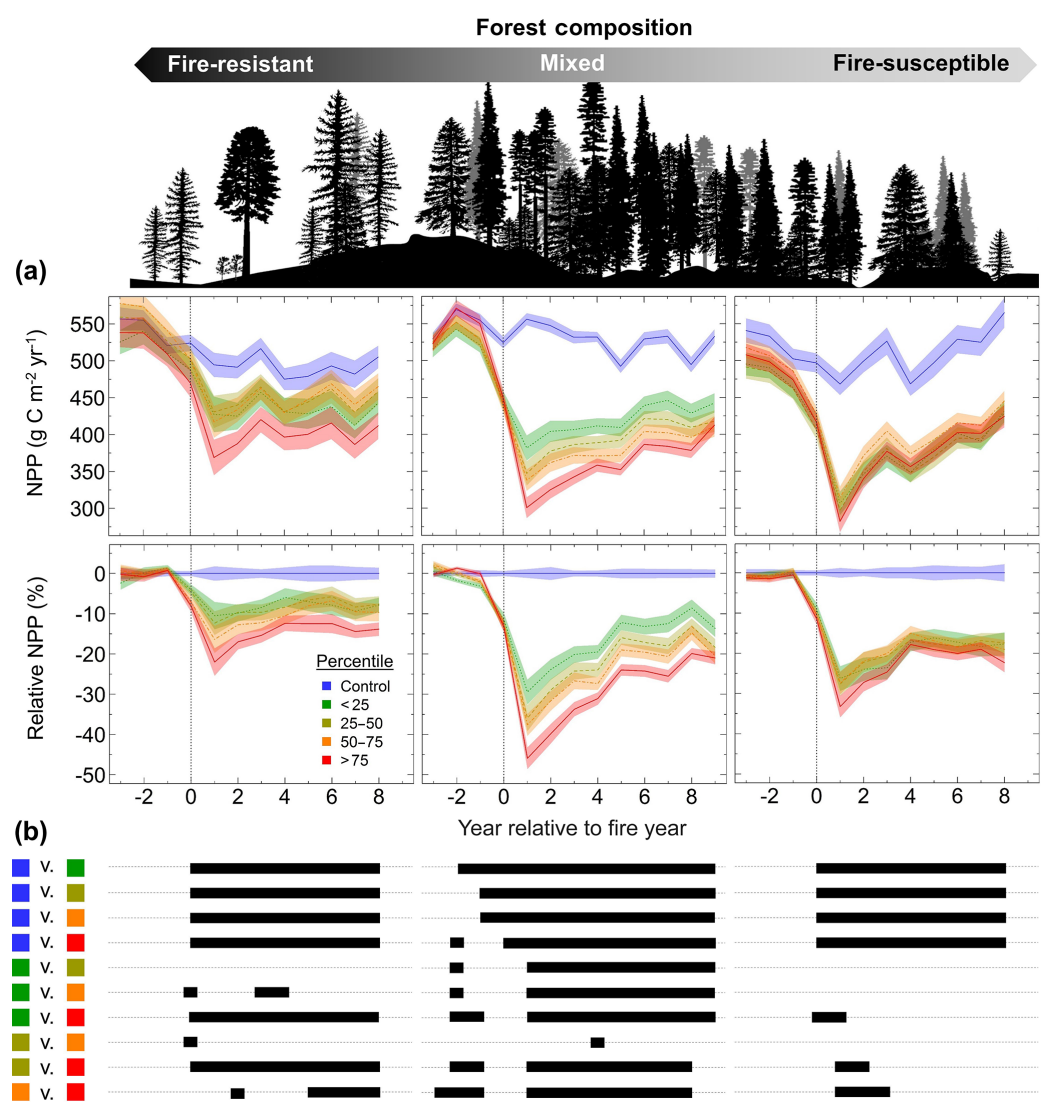

Figure 4. Fire intensity impacts on net primary productivity. (a) FRE dose impacts on absolute NPP $\left(\mathrm{g} \mathrm{C} \mathrm{m}^{-2} \mathrm{yr}^{-1}\right)$ and relative NPP (\%) observed in forests dominated by species varying from fire-resistant to fire-susceptible (first column-third column). NPP is grouped by FRE percentile classes and shading represents $95 \%$ confidence intervals in all panes. Gray dotted line marks fire year. (b) Results from ANOVA with a post hoc Tukey's honest significant difference test $(\alpha=0.05)$. Black bars indicate years where relative NPP groups differed.

ous studies have indicated that smaller trees are more susceptible to fire-induced mortality than larger trees (Hood et al., 2007). Additionally, there is evidence that similar FRP doses can lead to widely different growth responses depending on tree age (Smith et al., 2017; Sparks et al., 2017). For example, 2.5-year-old Pinus contorta and Larix occidentalis saplings exposed to highly controlled laboratory surface fires (peak FRP ranged from 4.1 to $12.9 \mathrm{~kW} \mathrm{~m}^{-2}$ ) had radial growth at 1-year post-fire that was -2.5 to $-20 \%$ of unburned saplings (Smith et al., 2017). In contrast, a similar range of peak FRP $\left(0.2-16.3 \mathrm{~kW} \mathrm{~m}^{-2}\right)$ was observed in prescribed fires in 34-year-old Pinus ponderosa stands, but resulted in tree radial growth that was -10 to $-45 \%$ of unburned tree radial growth at 1.5 years post-fire (Sparks et al., 2017). The forests analyzed in this study likely had highly heterogeneous stand structures and ages within each $1 \mathrm{~km}$ MODIS pixel, which could lead to highly heterogenous fire behavior and vegetation response within a pixel. While previous studies mainly assessed surface fire impacts on trees, it is likely that areas within each of the fires in this study had complete overstory removal via crown fire. Variability in fire behavior can also lead to unburned islands within each fire perimeter. Previous studies have quantified unburned proportions within MTBS perimeters ranging from $\sim 10$ to $25 \%$ of the within-perimeter area (Kolden et al., 2015; Meddens et al., 2016), which could lead to more mixed pixels (pixels containing burned and unburned forest). These subpixel differences could lead to widely different patterns of mortality and recovery and mask any pixel-scale dose-response relationship.

The observed dose-response relationship was likely affected by the number of MODIS FRP observations per pixel. Spatiotemporal aggregations of observations have been shown to substantially reduce uncertainties in sums of FRP (Freeborn et al., 2014). Due to the pixel-level variability in ages and species composition in these forests, only temporal FRP aggregations were employed in this paper. There were many pixels with few (1-2) MODIS FRP observations and large NPP losses (Fig. 3). This pattern could be attributed to greater FRP uncertainty resulting from the long temporal intervals between consecutive satellite overpasses and, consequently, a poorer overall characterization of the fire behavior for a particular pixel (Giglio, 2007; Freeborn et al., 2014). This factor could also account for the slight differences ob- 


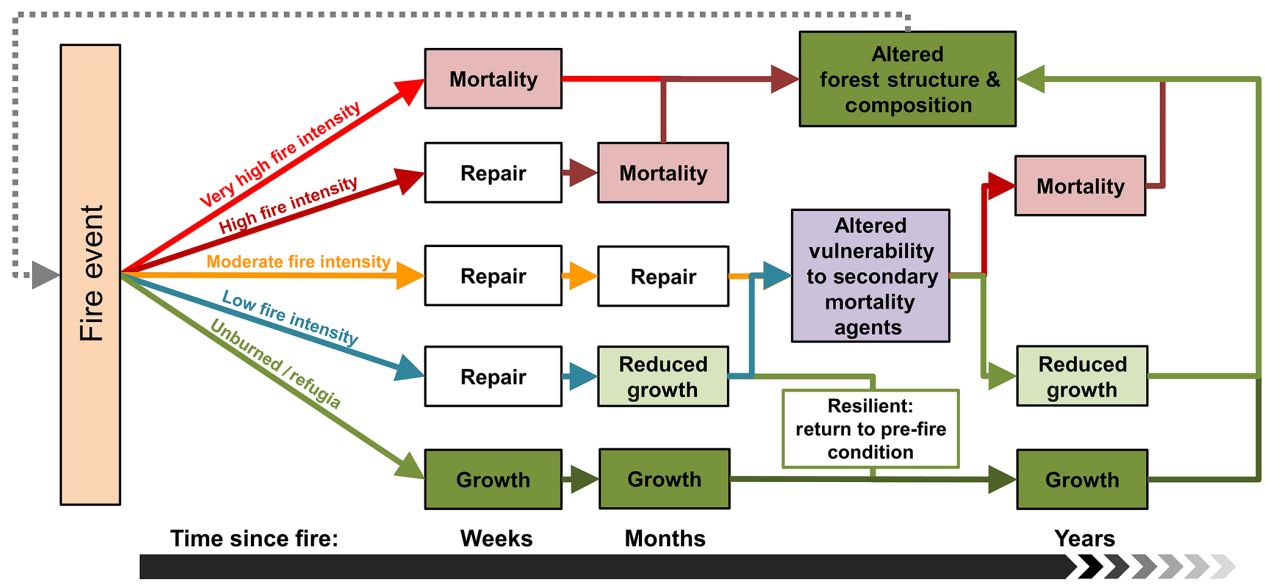

Figure 5. Conceptual framework for quantifying impacts of fire intensity on physiology, growth, and vulnerability of coniferous forests.

served between FRP metrics and FRE, as the long intervals between consecutive satellite overpasses have a high probability of missing increased fire activity associated with peak FRP (Giglio, 2007).

\subsection{Recovery and trajectories of post-fire NPP}

Despite an average post-fire observational period of 8.4 years across all fires, only the lowest FRP or FRE percentile class of one fire (2006 South Fork Fire) had recovered to pre-fire NPP levels $\sim 9$ years post-fire. Other studies that have used remote sensing observations reported recovery time ranging from 5 years (Goetz et al., 2006) to 9 years (Hicke et al., 2003) in boreal forests. Likewise, chronosequence studies in boreal forest have estimated recovery to be $\sim 10$ years (Amiro et al., 2010). The results from this study are consistent with observations showing large differences in productivity between burned and unburned forest stands at time periods greater than 10 years post-fire (Dore et al., 2008). The convergence of some of the NPP trajectories could be attributed to rapid recovery and colonization of fire-affected areas by understory species (Goetz et al., 2006). The forests in the current study occur in areas where rapid post-fire colonization by shrub and herbaceous species is common (Jorgensen and Jenkins, 2011), which could make NPP appear to recover more rapidly in areas where the forest overstory has been removed (Bright et al., 2013). Additionally, it is clear that variability in climate can significantly alter vegetation establishment and growth post-fire. Drier post-fire conditions can significantly reduce tree regeneration (Stevens-Rumann et al., 2017) and potentially lead to conversion to nonforest (Millar and Stephenson, 2015). Higher temperatures can also reduce tree growth and recovery, while increased precipitation can lead to greater growth (Bond-Lamberty et al., 2014). In this study, the incorporation of unburned pixels in the relative NPP calculation allowed for this methodology to control for climate variability and help isolate impacts resulting from the initial fire intensity.

\subsection{Conceptual framework for assessing spatiotemporal post-fire effects}

A growing number of studies have observed mechanistic links between fire intensity (or proxies of fire intensity such as crown scorch) and post-fire mortality and productivity in saplings (Sparks et al., 2016; Smith et al., 2017) and mature trees (Ryan and Reinhardt, 1988; Hood et al., 2007; Sparks et al., 2017). The results presented in this work, building upon tree-scale studies, suggest that such linkages scale to the landscape scale. However, it is clear that more ground measurements will be needed to confirm this hypothetical framework (Fig. 5). In this conceptual system, several postfire recovery pathways exist for trees or forests depending on the initial fire intensity. We hypothesize that higher intensity fires cause trees to incur more damage, which can lead to rapid mortality if trees have insufficient resources to repair physiological function in the weeks and months following a fire. The highest fire intensities lead to the greatest losses in physiological function and net primary productivity in surviving trees (Smith et al., 2017; Sparks et al., 2017) as well as the highest probability of delayed mortality in the years after a fire (Sparks et al., 2016). Several studies have observed heat-induced cavitation in xylem conduits of cut plant segments (Michaletz et al., 2012; West et al., 2016), leading to the hypothesis that reduced xylem conductivity is a dominant mechanism behind fire-caused mortality (Kavanagh et al., 2010; van Mantgem et al., 2013). Moderate levels of fire intensity cause enough damage to decrease growth and productivity and alter a tree's vulnerability to secondary mortality agents (e.g., insects, disease, and drought). Vulnerability may be lessened if permanent defensive structures, such as resin ducts in Pinus species used for expelling bark beetles, are induced by the fire (Hood et al., 2015; Sparks et al., 2017). 
On the contrary, fire may make trees more susceptible to secondary mortality agents if the photosynthetic machinery of trees is sufficiently impaired (Davis et al., 2012). Trees experiencing low-intensity fires will likely have reduced growth, but a higher probability of surviving than trees subjected to higher fire intensities. For any post-fire pathway, trees in better physiological condition or those exposed to fewer environmental stressors will likely experience a lower impact to post-fire growth and a lower probability of mortality.

\subsection{Limitations}

The dose-response relationship we observed between FRP or FRE and post-fire NPP does not necessarily mean this methodology can now be directly applied to the characterization of landscape-scale $\mathrm{C}$ dynamics; several limitations need to be considered. First, this study analyzed fires that occurred in forests with little-to-no management disturbance. Applying this methodology to managed forests may produce significantly different results, as land management disturbances (e.g., timber harvest, urban development) may alter the dose-response relationship between FRP and NPP. Second, in forests with less than $100 \%$ canopy cover, or where fire has completely removed the overstory, MODIS observes reflectance from overstory and understory forest vegetation. Understory vegetation that recovers rapidly could alter the magnitude of post-fire NPP reduction and make it appear that the overstory recovers more (or less) quickly. Finally, due to the fact that MODIS FRP observations per pixel were generally low $\left(\right.$ mean $=3.9$ observations pixel ${ }^{-1}$ ), caution should be used when interpreting results and comparing to other ground- and remote-sensing-based measurements.

\section{Conclusions}

Through the use of remotely sensed fire radiative power and net primary productivity, we demonstrate that increasing FRP and FRE results in decreasing post-fire net primary productivity in coniferous forests, especially those dominated by fire-resistant tree species. This dose-response relationship appears to have a legacy effect on $\mathrm{C}$ dynamics, in some cases lasting beyond a decade post-fire. Species composition also influenced the magnitude of post-fire NPP loss, highlighting the importance of the relative fire resistance of forest species in accounting for post-fire $\mathrm{C}$ dynamics. While this doseresponse relationship is promising, our results indicate that a low number of FRP observations diminish the detectability of this relationship. Despite post-fire observations ranging up to 12 years, most of the forests had not recovered to pre-fire productivity levels, which agrees with field observations showing large differences in productivity between burned and unburned temperate forests up to a decade postfire (Dore et al., 2008). This study extends prior tree-scale dose-response studies and presents a conceptual framework for using fire radiative metrics to quantify long-term postfire effects, such as reduction and recovery of NPP, on the landscape spatial scale. Ultimately, this study could serve as a basis for new questions surrounding variability in post-fire recovery within forested ecosystems on large spatial scales.

Data availability. All data can be obtained upon request to the authors.

\section{The Supplement related to this article is available online at https://doi.org/10.5194/bg-15-1173-2018-supplement.}

Competing interests. The authors declare that they have no conflict of interest.

Disclaimer. The article's content is solely the responsibility of the authors and does not necessarily represent the views of the NW CSC or the USGS.

Acknowledgements. The authors thank the anonymous reviewers for their insightful comments. Partial funding for Sparks was provided by the Joint Fire Science Program under GRIN Award 16-2-01-09. This material is based upon work supported by the National Science Foundation under grant no. DMS-1520873, and the Department of the Interior Northwest Climate Science Center (NW CSC) through a Cooperative Agreement (G14AP00177) from the United States Geological Survey (USGS).

Edited by: Trevor Keenan

Reviewed by: two anonymous referees

\section{References}

Abatzoglou, J. T. and Williams, A. P.: Impact of anthropogenic climate change on wildfire across western US forests, P. Natl. Acad. Sci. USA, 113, 11770-11775, https://doi.org/10.1073/pnas.1607171113, 2016.

Amiro, B. D., Barr, A. G., Barr, J. G., Black, T. A., Bracho, R., Brown, M., Chen, J., Clark, K. L., Davis, K. J., Desai, A. R., Dore, S., Engel, V., Fuentes, J. D., Goldstein, A. H., Goulden, M. L., Kolb, T. E., Lavigne, M. B., Law, B. E., Margolis, H. A., Martin, T., McCaughey, J. H., Misson, L., Montes-Helu, M., Noormets, A., Randerson, J. T., Starr, G., and Xiao, J.: Ecosystem carbon dioxide fluxes after disturbance in forests of North America, J. Geophys. Res.-Biogeo., 115, G00K02, https://doi.org/10.1029/2010JG001390, 2010.

Andela, N., Kaiser, J. W., van der Werf, G. R., and Wooster, M. J.: New fire diurnal cycle characterizations to improve fire radiative energy assessments made from MODIS observations, Atmos. Chem. Phys., 15, 8831-8846, https://doi.org/10.5194/acp15-8831-2015, 2015. 
Balshi, M. S., Mcguire, A. D., Duffy, P., Flannigan, M., Kicklighter, D. W., and Melillo, J.: Vulnerability of carbon storage in North American boreal forests to wildfires during the 21st century, Glob. Chang. Biol., 15, 1491-1510, https://doi.org/10.1111/j.1365-2486.2009.01877.x, 2009.

Barbero, R., Abatzoglou, J. T., Larkin, N. K., Kolden, C. A., and Stocks, B.: Climate change presents increased potential for very large fires in the contiguous United States, Int. J. Wildland Fire, 24, 892-899, https://doi.org/10.1071/WF15083, 2015.

Bonan, G. B.: Forests and Climate Change: Forcings, Feedbacks, and the Climate Benefits of Forests, Science, 320, 1444-1449, https://doi.org/10.1126/science.1155121, 2008.

Bond-Lamberty, B., Rocha, A. V., Calvin, K., Holmes, B., Wang, C., and Goulden, M. L.: Disturbance legacies and climate jointly drive tree growth and mortality in an intensively studied boreal forest, Glob. Change Biol., 20, 216-227, https://doi.org/10.1111/gcb.12404, 2014.

Boschetti, L. and Roy, D. P.: Strategies for the fusion of satellite fire radiative power with burned area data for fire radiative energy derivation, J. Geophys. Res.-Atmos., 114, 1-10, https://doi.org/10.1029/2008JDO11645, 2009.

Bowman, D. M. J. S., Balch, J. K., Artaxo, P., Bond, W. J., Carlson, J. M., Cochrane, M. A., D’Antonio, C. M., DeFries, R. S., Doyle, J. C., Harrison, S. P., Johnston, F. H., Keeley, J. E., Krawchuk, M. A., Kull, C. A., Marston, J. B., MaxA.Moritz, Prentice, I. C., Roos, C. I., Scott, A. C., Swetnam, T. W., van der Werf, G. R., and Pyne, S. J.: Fire in the Earth System, Science, 324, 481-484, https://doi.org/10.1126/science.1163886, 2009.

Bowman, D. M. J. S., Williamson, G. J., Abatzoglou, J. T., Kolden, C. A., Cochrane, M. A., and Smith, A. M. S.: Human exposure and sensitivity to globally extreme wildfire events, Nat. Ecol. Evol., 1, 58, https://doi.org/10.1038/s41559-016-0058, 2017.

Brewer, N. W., Smith, A. M. S., Hatten, J. A., Higuera, P. E., Hudak, A. T., Ottmar, R. D., and Tinkham, W. T.: Fuel moisture influences on fire-altered carbon in masticated fuels: An experimental study, J. Geophys. Res.-Biogeo., 118, 30-40, https://doi.org/10.1029/2012JG002079, 2013.

Bright, B. C., Hicke, J. A., and Meddens, A. J. H.: Effects of bark beetle-caused tree mortality on biogeochemical and biogeophysical MODIS products, J. Geophys. Res.-Biogeo., 118, 974-982, https://doi.org/10.1002/jgrg.20078, 2013.

Davis, R. S., Hood, S., and Bentz, B. J.: Fire-injured ponderosa pine provide a pulsed resource for bark beetles, Can. J. Forest Res., 42, 2022-2036, https://doi.org/10.1139/x2012-147, 2012.

de Groot, W. J., Flannigan, M. D., and Cantin, A. S.: Climate change impacts on future boreal fire regimes, Forest Ecol. Manag., 294, 35-44, https://doi.org/10.1016/j.foreco.2012.09.027, 2013.

Dore, S., Kolb, T. E., Montes-Helu, M., Sullivan, B. W., Winslow, W. D., Hart, S. C., Kaye, J. P., Koch, G. W., and Hungate, B. A.: Long-term impact of a stand-replacing fire on ecosystem $\mathrm{CO}_{2}$ exchange of a ponderosa pine forest, Glob. Change Biol., 14, 1801-1820, https://doi.org/10.1111/j.13652486.2008.01613.x, 2008.

Eidenshink, J. C., Schwind, B., Brewer, K., Zhu, Z.-L., Quayle, B., and Howard, S. M.: A project for monitoring trends in burn severity, Fire Ecol., 3, 3-21, 2007.

Fischer, W. C. and Bradley, A. F.: Fire Ecology of Western Montana Forest Habitat Types, USDA Forest Service General Technical Report, INT-GTR-223, Ogden, UT, 1987.
Freeborn, P. H., Wooster, M. J., Roy, D. P., and Cochrane, M. A.: Quantification of MODIS fire radiative power (FRP) measurement uncertainty for use in satellite-based active fire characterization and biomass burning estimation, Geophys. Res. Lett., 41, 1988-1994, https://doi.org/10.1002/2013GL059086, 2014.

Freeborn, P. H., Jolly, W. M., and Cochrane, M. A.: Impacts of changing fire weather conditions on reconstructed trends in U.S. wildland fire activity from 1979 to 2014, J. Geophys. Res.-Biogeo., 121, 2856-2876, https://doi.org/10.1002/2016JG003617, 2016.

Gergel, D. R., Nijssen, B., Abatzoglou, J. T., Lettenmaier, D. P., and Stumbaugh, M. R.: Effects of climate change on snowpack and fire potential in the western USA, Climatic Change, 141, 287299, https://doi.org/10.1007/s10584-017-1899-y, 2017.

Giglio, L.: Characterization of the tropical diurnal fire cycle using VIRS and MODIS observations, Remote Sens. Environ., 108, 407-421, https://doi.org/10.1016/j.rse.2006.11.018, 2007.

Giglio, L.: MODIS collection 6 active fire product user's guide, revision A, Technical Report, University of Maryland, available at: http://modis-fire.umd.edu/files/MODIS_C6_Fire_User_ Guide_A.pdf (last access: 23 February 2018), 2015.

Giglio, L., Csiszar, I., and Justice, C. O.: Global distribution and seasonality of active fires as observed with the Terra and Aqua Moderate Resolution Imaging Spectroradiometer (MODIS) sensors, J. Geophys. Res.-Biogeo., 111, 1-12, https://doi.org/10.1029/2005JG000142, 2006.

Giglio, L., Schroeder, W., and Justice, C. O.: The collection 6 MODIS active fire detection algorithm and fire products, Remote Sens. Environ., 178, 31-41, https://doi.org/10.1016/j.rse.2016.02.054, 2016.

Goetz, S. J., Fiske, G. J., and Bunn, A. G.: Using satellite time-series data sets to analyze fire disturbance and forest recovery across Canada, Remote Sens. Environ., 101, 352-365, https://doi.org/10.1016/j.rse.2006.01.011, 2006.

Goetz, S. J., Mack, M. C., Gurney, K. R., Randerson, J. T., and Houghton, R. A.: Ecosystem responses to recent climate change and fire disturbance at northern high latitudes: observations and model results contrasting northern Eurasia and North America, Environ. Res. Lett., 2, 45031, https://doi.org/10.1088/17489326/2/4/045031, 2007.

Harrington, M. G.: Duff mound consumption and cambium injury for centuries-old western larch from prescribed burning in western Montana, Int. J. Wildland Fire, 22, 359-367, https://doi.org/10.1071/WF12038, 2013.

Hasenauer, H., Petritsch, R., Zhao, M., Boisvenue, C. and Running, S. W.: Forest Ecology and Management Reconciling satellite with ground data to estimate forest productivity at national scales, Forest Ecol. Manag., 276, 196-208, https://doi.org/10.1016/j.foreco.2012.03.022, 2012.

He, T., Pausas, J. G., Belcher, C. M., Schwilk, D. W., and Lamont, B. B.: Fire-adapted traits of Pinus arose in the fiery Cretaceous, New Phytol., 194, 751-759, https://doi.org/10.1111/j.14698137.2012.04079.x, 2012.

Heward, H., Smith, A. M. S., Roy, D. P., Tinkham, W. T., Hoffman, C. M., Morgan, P., and Lannom, K. O.: Is burn severity related to fire intensity? Observations from landscape scale remote sensing, Int. J. Wildland Fire, 22, 910-918, https://doi.org/10.1071/WF12087, 2013. 
Hicke, J. A., Asner, G. P., Kasischke, E. S., French, N. H. F., Randerson, J. T., Collatz, G. J., Stocks, B. J., Tucker, C. J., Los, S. O., and Field, C. B.: Postfire response of North American boreal forest net primary productivity analyzed with satellite observations, Glob. Change Biol., 9, 1145-1157, https://doi.org/10.1046/j.1365-2486.2003.00658.x, 2003.

Holden, Z. A., Smith, A. M. S., Morgan, P., Rollins, M. G., and Gessler, P. E.: Evaluation of novel thermally enhanced spectral indices for mapping fire perimeters and comparisons with fire atlas data, Int. J. Remote Sens., 26, 4801-4808, https://doi.org/10.1080/01431160500239008, 2005.

Homer, C., Dewitz, J., Fry, J., Coan, M., Hossain, N., Larson, C., Herold, N., McKerrow, A., VanDriel, J. N., and Wickham, J.: Completion of the 2001 National Land Cover Database for the Conterminous United States, Photogramm. Eng. Rem. S., 73, 337-341, 2007.

Hood, S., Sala, A., Heyerdahl, E. K., Boutin, M., and Raffa, K. F.: Low-severity fire increases tree defense against bark beetle attacks, Ecology, 96, 1846-1855, https://doi.org/10.1890/140487.1, 2015.

Hood, S. M., McHugh, C. W., Ryan, K. C., Reinhardt, E., and Smith, S. L.: Evaluation of a post-fire tree mortality model for western USA conifers, Int. J. Wildland Fire, 16, 679-689, https://doi.org/10.1071/WF06122, 2007.

IPCC: Climate Change 2013: The Physical Science Basis. Contribution of Working Group I to the Fifth Assessment Report of the Intergovernmental Panel on Climate Change, edited by: Stocker, T. F., Qin, D., Plattner, G.-K., Tignor, M., Allen, S. K., Boschung, J., Nauels, A., Xia, Y., Bex, V., and Midgley, P. M., Cambridge University Press, Cambridge, UK and New York, NY, USA, 1535 pp., 2013.

Irvine, J., Law, B. E., and Hibbard, K. A.: Postfire carbon pools and fluxes in semiarid ponderosa pine in Central Oregon, Glob. Change Biol., 13, 1748-1760, https://doi.org/10.1111/j.13652486.2007.01368.x, 2007.

Jorgensen, C. A. and Jenkins, M. J.: Fuel complex alterations associated with spruce beetle-induced tree mortality in intermountain spruce/fir forests, Forest Sci., 57, 232-240, 2011.

Justice, C. O., Giglio, L., Korontzi, S., Owens, J., Morisette, J. T., Roy, D., Descloitres, J., Alleaume, S., Petitcolin, F., and Kaufman, Y.: The MODIS fire products, Remote Sens. Environ., 83, 244-262, https://doi.org/10.1016/S0034-4257(02)00076-7, 2002.

Kashian, D. M., Romme, W. H., Tinker, D. B., Turner, M. G., and Ryan, M. G.: Carbon Storage on Landscapes with Stand-replacing Fires, Bioscience, 56, 598-606, https://doi.org/10.1641/00063568(2006)56[598:CSOLWS]2.0.CO;2, 2006.

Kaufman, Y. J., Remer, L. A., Ottmar, R. D., Ward, D. E., Li, R. R., Kleidman, R., Fraser, R. S., Flynn, L., McDougal, D., and Shelton, G.: Relationship between remotely sensed fire intensity and rate of emission of smoke: SCAR-C experiment, Global Biomass Burning, edited by: Levin, J., 685-696, MIT Press, Cambridge, Mass., 1996.

Kavanagh, K. L., Dickinson, M. B., and Bova, A. S.: A way forward for fire-caused tree mortality prediction: modeling a physiological consequence of fire, Fire Ecol., 6, 80-94, 2010.
Keeley, J. E.: Ecology and evolution of pine life histories, Ann. For. Sci., 69, 445-453, https://doi.org/10.1007/s13595-012-0201-8, 2012.

Kolden, C. A., Abatzoglou, J. T., Lutz, J. A., Cansler, C. A., Kane, J. T., Van Wagtendonk, J. W., and Key, C. H.: Climate Contributors to Forest Mosaics: Ecological Persistence Following Wildfire, Northwest Sci., 89, 219-238, https://doi.org/10.3955/046.089.0305, 2015.

Kremens, R. L., Dickinson, M. B., and Bova, A. S.: Radiant flux density, energy density and fuel consumption in mixedoak forest surface fires, Int. J. Wildland Fire, 21, 722-730, https://doi.org/10.1071/WF10143, 2012.

Kumar, S. S., Roy, D. P., Boschetti, L., and Kremens, R.: Exploiting the power law distribution properties of satellite fire radiative power retrievals: A method to estimate fire radiative energy and biomass burned from sparse satellite observations, J. Geophys. Res.-Atmos., 116, 1-18, https://doi.org/10.1029/2011JD015676, 2011.

LANDFIRE: LANDFIRE Existing Vegetation Type layer, U.S. Department of Interior (update June 2013), Geological Survey, available at: http://landfire.cr.usgs.gov/viewer/ (last access: 23 February 2018), 2013.

Meddens, A. J. H., Kolden, C. A., and Lutz, J. A.: Detecting unburned areas within wildfire perimeters using Landsat and ancillary data across the northwestern United States, Remote Sens. Environ., 186, 275-285, https://doi.org/10.1016/j.rse.2016.08.023, 2016.

Michaletz, S. T., Johnson, E. A., and Tyree, M. T.: Moving beyond the cambium necrosis hypothesis of post-fire tree mortality: cavitation and deformation of xylem in forest fires, New Phytol., 194, 254-263, https://doi.org/10.1111/j.14698137.2011.04021.x, 2012.

Midgley, J. J., Kruger, L. M., and Skelton, R.: How do fires kill plants? The hydraulic death hypothesis and Cape Proteaceae "fire-resisters", S. Afr. J. Bot., 77, 381-386, https://doi.org/10.1016/j.sajb.2010.10.001, 2011.

Millar, C. I. and Stephenson, N. L.: Temperate forest health in an era of emerging megadisturbance, Science, 349, 823-826, https://doi.org/10.1126/science.aaa9933, 2015.

Morgan, P., Hardy, C. C., Swetnam, T. W., Rollins, M. G., and Long, D. G.: Mapping fire regimes across time and space: understanding coarse and fine-scale fire patterns, Int. J. Wildland Fire, 10, 329-342, https://doi.org/10.1071/WF01032, 2001.

Roberts, G., Wooster, M. J., Freeborn, P. H., and Xu, W.: Integration of geostationary FRP and polar-orbiter burned area datasets for an enhanced biomass burning inventory, Remote Sens. Environ., 115, 2047-2061, https://doi.org/10.1016/j.rse.2011.04.006, 2011.

Rogers, B. M., Soja, A. J., Goulden, M. L., and Randerson, J. T.: Influence of tree species on continental differences in boreal fires and climate feedbacks, Nat. Geosci., 8, 228-234, https://doi.org/10.1038/ngeo2352, 2015.

Romme, W. H., Boyce, M. S., Gresswell, R., Merrill, E. H., Minshall, G. W., Whitlock, C., and Turner, M. G.: Twenty Years After the 1988 Yellowstone Fires: Lessons About Disturbance and Ecosystems, Ecosystems, 14, 1196-1215, https://doi.org/10.1007/s10021-011-9470-6, 2011.

Running, S. W., Nemani, R. R., Heinsch, F. A., Zhao, M., Reeves, M., and Hashimoto, H.: A Continuous Satellite- 
Derived Measure of Global Terrestrial Primary Production, Bioscience, 54, 547-560, https://doi.org/10.1641/00063568(2004)054[0547:ACSMOG]2.0.CO;2, 2004.

Ryan, K. C. and Reinhardt, E. D.: Predicting postfire mortality of seven western conifers, Can. J. Forest Res., 18, 1291-1297, https://doi.org/10.1139/x88-199, 1988.

Schoennagel, T., Veblen, T. T., and Romme, W. H.: The interaction of fire, fuels, and climate across Rocky Mountain forests, Bioscience, 54, 661-676, https://doi.org/10.1641/00063568(2004)054[0661:TIOFFA]2.0.CO;2, 2004.

Shinneman, D. J. and Baker, W. L.: Nonequilibrium Dynamics between Catastrophic Disturbances and Old-Growth Forests in Ponderosa Pine Landscapes of the Black Hills, Cons. Biol., 11, 1276-1288, https://doi.org/10.1046/j.1523-1739.1997.96198.x, 1997.

Smith, A. M. S. and Wooster, M. J.: Remote classification of head and backfire types from MODIS fire radiative power and smoke plume observations, Int. J. Wildland Fire, 14, 249-254, https://doi.org/10.1071/WF05012, 2005.

Smith, A. M. S., Sparks, A. M., Kolden, C. A., Abatzoglou, J. T., Talhelm, A. F., Johnson, D. M., Boschetti, L., Lutz, J. A., Apostol, K. G., Yedinak, K. M., Tinkham, W. T., and Kremens, R. J.: Towards a new paradigm in fire severity research using dose - response experiments, Int. J. Wildland Fire, 25, 158-166, https://doi.org/10.1071/WF15130, 2016.

Smith, A. M. S., Talhelm, A. F., Johnson, D. M., Sparks, A. M., Kolden, C. A., Yedinak, K. M., Apostol, K. G., Tinkham, W. T., Abatzoglou, J. T., Lutz, J. A., Davis, A. S., Pregitzer, K. S., Adams, H. D., and Kremens, R. L.: Effects of fire radiative energy density dose on Pinus contorta and Larix occidentalis seedling physiology and mortality, Int. J. Wildland Fire, 26, 8294, https://doi.org/10.1071/WF16077, 2017.

Sparks, A., Kolden, C., Talhelm, A., Smith, A., Apostol, K., Johnson, D., and Boschetti, L.: Spectral Indices Accurately Quantify Changes in Seedling Physiology Following Fire: Towards Mechanistic Assessments of Post-Fire Carbon Cycling, Remote Sens., 8, 572, https://doi.org/10.3390/rs8070572, 2016.

Sparks, A. M., Smith, A. M. S., Talhelm, A. F., Kolden, C. A., Yedinak, K. M., and Johnson, D. M.: Impacts of fire radiative flux on mature Pinus ponderosa growth and vulnerability to secondary mortality agents, Int. J. Wildland Fire, 26, 95-106, https://doi.org/10.1071/WF16139, 2017.

Starker, T.: Fire Resistance in the Forest, J. Forest, 32, 462-467, 1934.

Stevens-Rumann, C. S., Kemp, K. B., Higuera, P. E., Harvey, B. J., Rother, M. T., Donato, D. C., Morgan, P., and Veblen, T. T.: Evidence for declining forest resilience to wildfires under climate change, Ecol. Lett., https://doi.org/10.1111/ele.12889, 2017.
Tinkham, W. T., Smith, A. M. S., Higuera, P. E., Hatten, J. A., Brewer, N. W., and Doerr, S. H.: Replacing time with space: Using laboratory fires to explore the effects of repeated burning on black carbon degradation, Int. J. Wildland Fire, 25, 242-248, https://doi.org/10.1071/WF15131, 2016.

VanderWeide, B. L. and Hartnett, D. C.: Fire resistance of tree species explains historical gallery forest community composition, Forest Ecol. Manage., 261, 1530-1538, https://doi.org/10.1016/j.foreco.2011.01.044, 2011.

Van Mantgem, P. J., Nesmith, J. C., Keifer, M., Knapp, E. E., Flint, A., and Flint, L.: Climatic stress increases forest fire severity across the western United States, Ecol. Lett., 16, 1151-1156, https://doi.org/10.1111/ele.12151, 2013.

Vermote, E., Ellicott, E., Dubovik, O., Lapyonok, T., Chin, M., Giglio, L., and Roberts, G. J.: An approach to estimate global biomass burning emissions of organic and black carbon from MODIS fire radiative power, J. Geophys. Res.-Atmos., 114, D18205, https://doi.org/10.1029/2008JD011188, 2009.

West, A. G., Nel, J. A., Bond, W. J., and Midgley, J. J.: Experimental evidence for heat plume-induced cavitation and xylem deformation as a mechanism of rapid post-fire tree mortality, New Phytol., 211, 828-838, https://doi.org/10.1111/nph.13979, 2016.

Wolfe, R. E., Roy, D. P., and Vermote, E.: MODIS land data storage, gridding, and compositing methodology: Level 2 grid, IEEE T. Geosci. Remote Sens., 36, 1324-1338, https://doi.org/10.1109/36.701082, 1998.

Wooster, M. J., Zhukov, B., and Oertel, D.: Fire radiative energy for quantitative study of biomass burning: derivation from the BIRD experimental satellite and comparison to MODIS fire products, Remote Sens. Environ., 86, 83-107, https://doi.org/10.1016/S0034-4257(03)00070-1, 2003.

Wooster, M. J., Roberts, G., Perry, G. L. W., and Kaufman, Y. J.: Retrieval of biomass combustion rates and totals from fire radiative power observations: FRP derivation and calibration relationships between biomass consumption and fire radiative energy release, J. Geophys. Res.-Atmos., 110, 1-24, https://doi.org/10.1029/2005JD006318, 2005.

Zhao, M. and Running, S. W.: Drought-Induced Reduction in Global Terrestrial Net Primary Production from 2000 through 2009, Science, 329, 940-943, https://doi.org/10.1126/science.1192666, 2010. 